Cell Research (2003); 13(3):203-209

http://www.cell-research.com

\title{
Coxsackievirus B3-induced apoptosis and Caspase-3
}

\author{
Jian Ping YUAN, Wei ZHAO, Hong Tao WANG, Kai Yu WU, Tao LI, Xiao Kui GUO*, Shan Qing \\ TONG
}

Department of Microbiology and Parasitology, Shanghai Second Medical University, Shanghai 200025, China

\begin{abstract}
Cell death can be classified into two categories: apoptosis and necrosis. Apoptotic pathway can be either caspase-dependent or caspase-independent. Caspase-independent cytopathic effect (CPE) has been described. In order to evaluate the pattern of HeLa cell death induced by Coxsackievirus B3 (CVB3) and whether apoptosis involves caspase activation, we co-cultivated HeLa cells with CVB3 and detected the cytopathic changes, the alteration of mRNA and protein expression of caspase-3 gene plus caspase-3 activity, as well as analyzing DNA fragmentation before and after caspase-3 activity inhibition. According to the results, we propose that CVB3 may induce apoptosis and necrosis in HeLa cells, the latter appearing much earlier. Caspase-3 is activated at the levels of both transcription and translation, and procaspase-3 is proteolytically cleaved, thus leading to the continuous increasing of both caspase-3 precursor protein and its subunit. However, besides CPE, apoptosis induced by CVB3 is not a direct consequence of the activation of caspase-3, or caspase-3 is not the only effector molecule in apoptotic cell death, for caspase-3 inhibitor can not decrease DNA fragmentation. Some other biochemical mechanisms may participate in the process, whose role weakens the effect of inhibiting caspase-3 activity.
\end{abstract}

Key words: Coxsackievirus B3 (CVB3), apoptosis, caspase-3.

\section{INTRODUCTION}

Coxsackievirus B3 (CVB3) is an enterovirus in the family Picornaviridae which is an etiologic agent of many kinds of human diseases that range in severity from non-symptom to lethal infections[1]. Upon entering the cells, translation of CVB3 genome by the host translational machinery produces a single polyprotein. Subsequent autolytic cleavages of the polyprotein generate various structural and nonstrutural proteins that are responsible for the subsequent viral replication and pathogenesis[2]. Pre-

\footnotetext{
* Correspondence: Prof. Xiao Kui GUO,Department of Microbiology and Parasitology, Shanghai Second Medical University, 280 Chongqingnan Road, Shanghai 200025, China E-mail: xkguo@shsmu.edu.cn Tel: 0086-21-64671226 Fax: 0086-2164671226

Received Dec-11-2001 Revised Feb-10-2003 Accepted Feb-24-2003
}

vious researches have revealed two types of cell death induced by picornavirus: a violent, rapid necrosis characterized by cytoplasmic swelling, membrane rupturing and organelle dissolution with relatively unremarkable nuclear changes and a more protracted, morphologically distinct apoptosis when cells shrink, dissociate from neighbors, leave their organelles mostly intact but show extensive nuclear fragmentation and expose novel surface molecules for rapid phagocytosis[3-6].

Over the past years, a number of studies have added to the data defining the aberrant induction of apoptosis, among which much attention has been paid to caspases, a family of cysteine protease with specificity for aspartic acid residues and play a significant role in the proteolytic cleavage of certain structural and functional proteins which may contribute to the manifestation of the apoptotic pheno- 
type[7, 8]. Based upon their functions, caspases can be classified into three groups: the first group (caspases $1,4,5,11-14$ ) with a limited role in apoptosis mainly participates in inflammation; the second group (caspase 2, 8-10) as initiators of apoptosis; and the third group (caspases $3,6,7$ ) as effectors of apoptosis[9]. Upon receipt of a death signal, a cascade of proteolytic cleavages results in activation of preexisting inactive caspases, which cleave specific substrates such as DNA fragmentation factor (DFF) and poly (ADP-ribose) polymerase (PARP), resulting in apoptosis and corresponding cell morphological \& structural changes[10]. Several apoptosis-inducing signals including virus infection have been shown to activate caspases[11-14]. However, various recent reports indicated the existence of caspase-independent apoptosis[15-18]. Carthy et al observed the alteration of the amount of caspase-3 protein and its proteolytical activity as well, following co-cultivating HeLa cells with CVB3. The results suggested that caspase activation and cleavage of substrates may not be responsible for the characteristic cytopathic effect produced by picornavirus infection[19]. But they did not elucidate the relationship between caspases and apoptosis other than cytopathic effect (CPE), which is determined only by morphological observation with contrast microscopy.

In order to further clarify the forms of cell death after CVB3 infection of cells, along with whether caspases are involved in the process of cell death, we detected cytopathic changes of HeLa cells, measured changing of caspase-3 at the levels of transcription and translation, and analyzed DNA fragmentation before and after caspase-3 activity inhibition, expecting to have a better understanding of the mechanisms of cell death induced by picornavirus.

\section{MATERIALS AND METHODS}

\section{Cells and viral infection}

HeLa cells were cultivated in RPMI 1640 with $10 \%$ fetal calf serum and propagated at $37^{\circ} \mathrm{C}-5 \% \mathrm{CO}_{2}$ in humidified chamber, and then were co-cultivated with Coxsackievirus B3 (TCID50= $10^{-7.7}$ ) maintained by our laboratory for $1 \mathrm{~h}$. Cells were then washed with phosphate buffered saline (PBS), and RPMI 1640 with $2 \%$ fetal calf serum was substituted. Cultures were observed by phase contrast microscopy and harvested at 0, 1, 6, 12, 18, 24, 30, 36, 42 $\mathrm{h}$ postinfection in different ways according to different objectives.

\section{Electron microscopy}

Cells were washed with PBS and fixed in glutaraldehyde followed by osmium tetroxide, dehydrated in graded ethanols, and embedded in Spurr resin. Ultrathin sections were counterstained with uranyl acetate and lead citrate before examination under the electron microscope.

Fluorescence activated cell sorting (FACS) and detection apoptosis

Cells were digested by $0.05 \%$ trypsin, washed with PBS, and fixed in $70 \%$ ethanol at $4^{\circ} \mathrm{C}$ Following filtration, cells were stained by propidium iodide (PI) containing $100 \mu \mathrm{g} / \mathrm{ml} \mathrm{RNase}$ and detected of apoptosis by FACS.

\section{$R T-P C R$}

RNA was isolated from cells using TRIZOL reagent (GIBCOBRL, Life Technologies) in accordance with the protocol provided by the manufacturer. Then, the reverse transcription (RT) reaction for synthesis of cDNA was performed, using a 18mer oligod(T) primer (Sangon) and moloney murine leukemia virus reverse transcriptase (MBI Fermentas). The reverse transcription product was then used as a template for PCR using two specific primers and two GAPDH primers as follows: (i) Specific primers (Ref.9) : 5' CAG AGG GGA TCG TTG TAG AAG 3' , and 5' GTT GCC ACC TTT CG TTA ACC 3' ; (ii) GAPDH primers: 5' ATG GCA CCG TCA AGG CTG AG 3' , and 5' CGC CTG CTT CAC CAC CTT CT' .

\section{Western blot analysis}

Protein was isolated from cells using TRIZOL reagent and then subjected to SDS-PAGE. Resolved proteins were electrophoretically transferred to cellulosenitrate membrane (Schleicher and Schuell). The membrane was incubated in PBS containing 5\% nonfat dry milk for $2 \mathrm{~h}$ at room temperature, and then incubated with a rabbit polyclonal antibody (1:200 dilution) against caspase3 (Santa Cruz Biotechnology, Inc.) in the same buffer for $2 \mathrm{~h}$ at 4 ${ }^{\circ} \mathrm{C}$. Then, the membrane was thoroughly washed in a buffer containing $150 \mathrm{mM} \mathrm{NaCl}$ and $50 \mathrm{mM}$ Tris ( $\mathrm{pH}$ 7.5), followed by incubating in the same buffer containing $5 \%$ nonfat dry milk and anti-rabbit IgG-HRP (Santa Cruz Biotechnology, Inc.) diluted at 1:400 for $1 \mathrm{~h}$ at room temperature. After incubation, the membrane was then washed in the same buffer and developed with a solution of 3, 3' -Diaminobenzidine (DAB).

Assay of caspase-3 activity with ApoAlert Caspase3 Colorimetric Assay Kit (Clontech)

$2 \times 10^{6}$ cells were counted and centrifuged at $400 \times \mathrm{g}$ for $10 \mathrm{~min}$, resuspended in $50 \mathrm{ml}$ of chilled cell lysis buffer, and then incubated on ice for $10 \mathrm{~min}$. Cell lysates were centrifuged at $12000 \times \mathrm{g}$ for $3 \mathrm{~min}$ at $4^{\circ} \mathrm{C}$ to precipitate cellular debris. $50 \mu \mathrm{l}$ of $2 \times$ reaction buffer/DTT Mix and $5 \mu \mathrm{l}$ of $1 \mathrm{~m} M$ Caspase substrate DEVD-pNA were added to each transferred supernatant. The samples were incubated at $37^{\circ} \mathrm{C}$ for $1 \mathrm{~h}$ in a water bath, and then were read at $405 \mathrm{~nm}$ in a microplate reader.

Inhibition of caspase-3 activity 
$20 \mu M$ caspase-3 inhibitor DEVD-fmk (clontech) was incubated with HeLa cells for $2 \mathrm{~h}$ prior to infection of CVB3. After CVB3 infection, the cells were washed with PBS, and RPMI 1640 containing $10 \%$ fetal calf serum and fresh DEVD-fmk were substituted. Cells were collected at different times, and then were assayed of caspase-3 activity, as well as detected of apoptosis by FACS.

\section{RESULTS}

\section{Cell death pattern in CVB3-infected HeLa cells}

From 6 h postinfection by CVB3, distinct morphological changes had occurred in some of the cells when the cells condensed and rounded, with more granules appearing, and finally released from the monolayer (Fig 1). From 6 h postinfection by CVB3, pathological changes had begun to appear in some of the cells, with dissolved cytoplasm, broken or ganelles, and ruptured membrane. CVB3 just as sembled could be seen. As time went by, more and more cells degenerated. By $24 \mathrm{~h}$ postinfection, many cells showed morphological evidence of apoptosis, such as shrinked cells, distorted nucleus with condensed chromatin, reserved organelles, intact membrane, and sometimes apoptotic bodies appearing in the neighborhood (Fig 2). This result suggests that CVB3 may induce apoptosis and necrosis in HeLa cells, and the latter appears much earlier.

Little apoptosis was detected by FACS between 0 and $12 \mathrm{~h}$ postinfection, while distinct subdiploid peak could be seen by $24 \mathrm{~h}$ postinfection, with the proportion of apoptotic cells reaching $23.96 \%$. As time went by, the proportion of apoptotic cells increases, till achieving $54.85 \%$ by $42 \mathrm{~h}$ postinfection (Fig 3a). In cells pre-incubated with DEVD-fmk, no distinct difference was found in detecting apoptosis by FACS (Fig $3 b$ ).

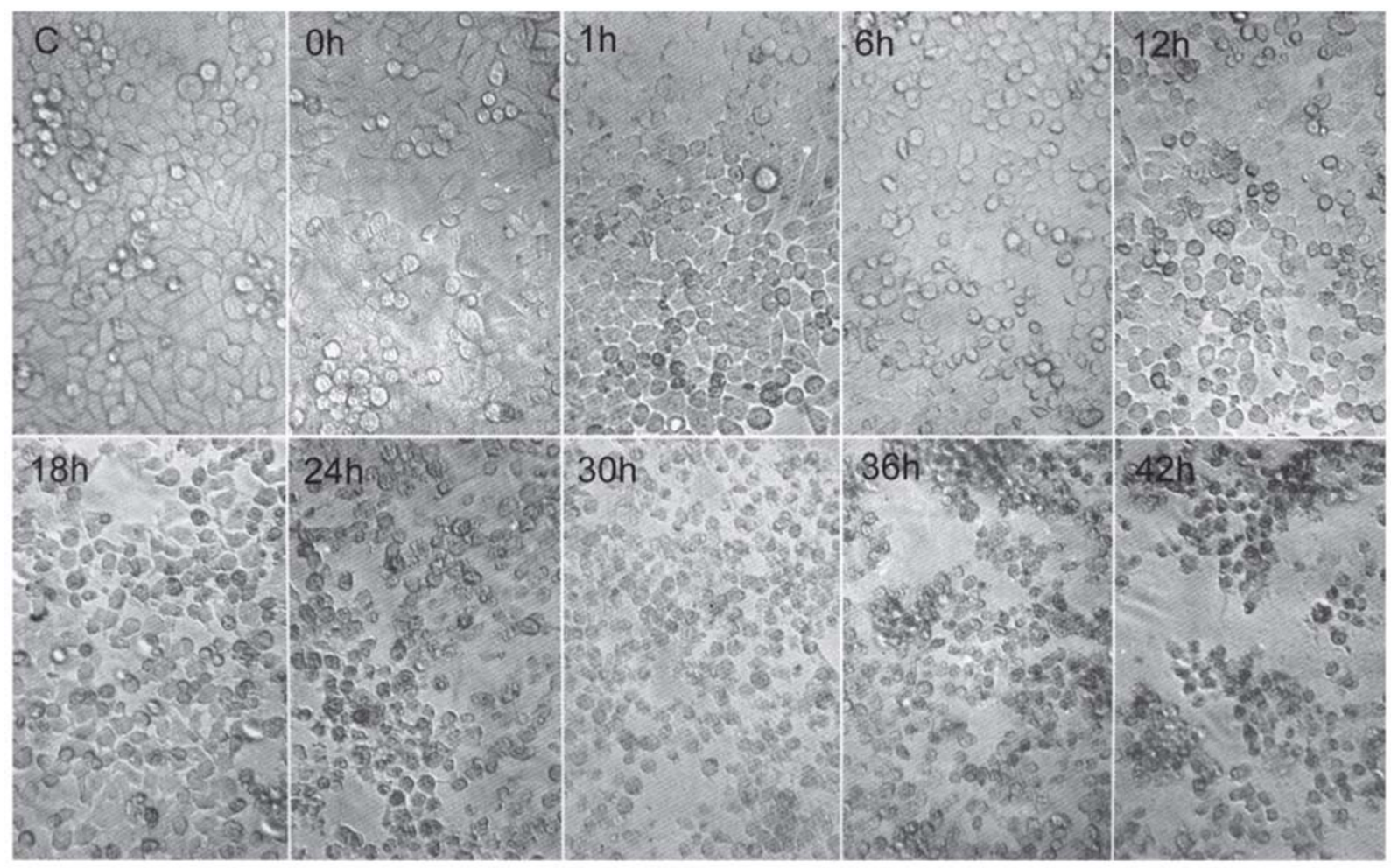

Fig 1. Coxsackievirus B3 infection in HeLa cells $(320 \times)$. From 6 h postinfection by CVB3, distinct morphological changes had been observed with phase contrast microscopy when the cells condensed and rounded, with more granules appearing in, and finally released from the monolayer. C, Uninfected control HeLa cells. Other photos show the CVB3infected HeLa cells harvested from $0 \mathrm{~h}$ to $42 \mathrm{~h}$ after infection. 

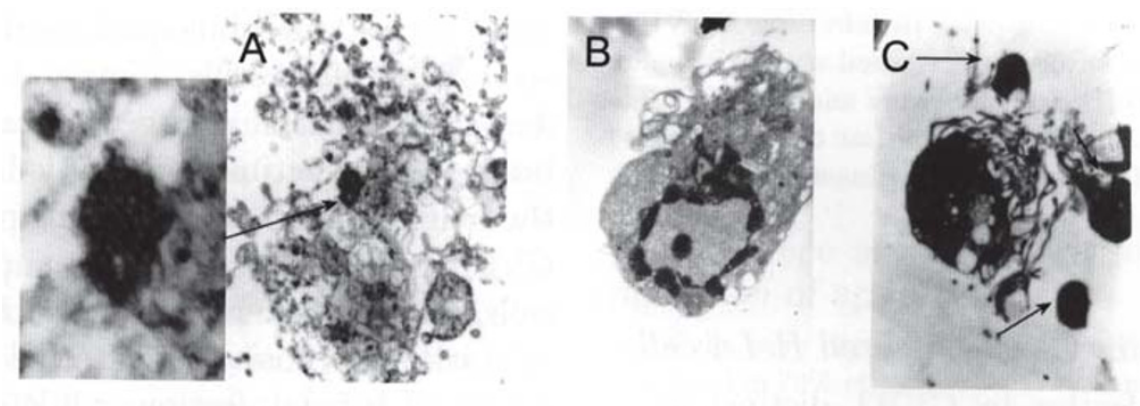

Fig 2. HeLa cell morphology under electron microscopy (A) 12 h postinfection, necrotic cell with dissolved cytoplasm, broken organelles, and ruptured membrane was observed. CVB3 just assembled can be seen (pointed by the arrow head) $(8000 \times)$. (B) $24 \mathrm{~h}$ postinfection, apoptotic cell was observed: the cell shrinks, the nucleus distorts with condensing chromatin, the microvilli disappear, while the organelles reserve and the membrane is still intact $(4000 \times)$. $(\mathbf{C})$ Apoptotic cell and apoptotic bodies (pointed by the arrow heads) observed by $24 \mathrm{~h}$ postinfection $(5000 \times)$.

A

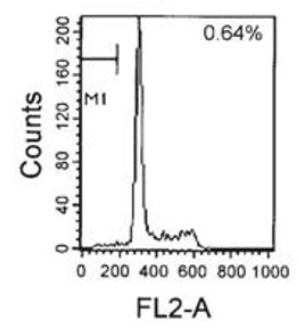

$18 \mathrm{~h}$

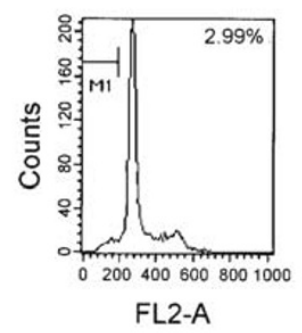

B

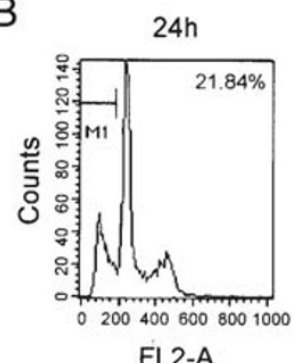

FL2-A

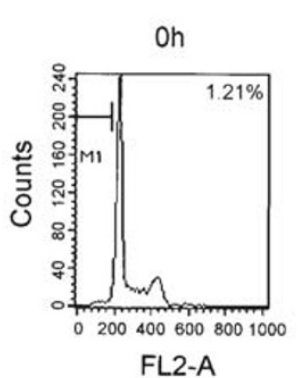

$24 \mathrm{~h}$
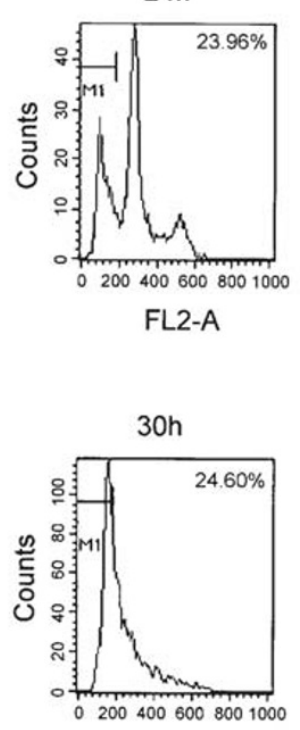

FL2-A

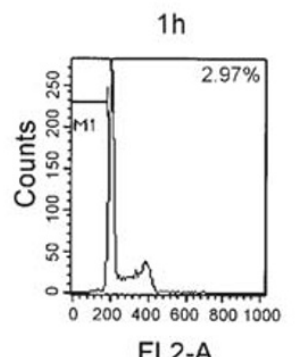

FL2-A
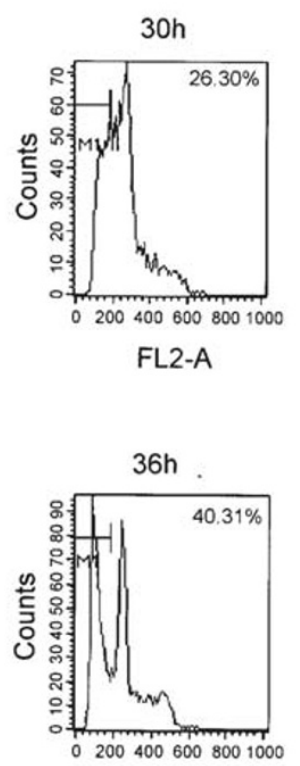

FL2-A

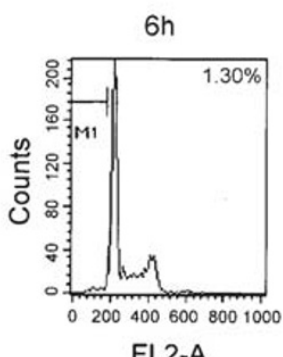

FL2-A
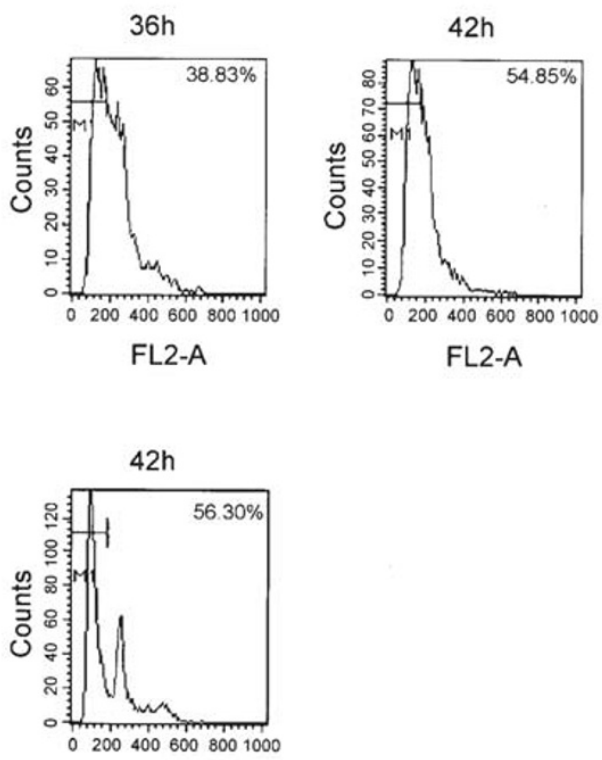

FL2-A

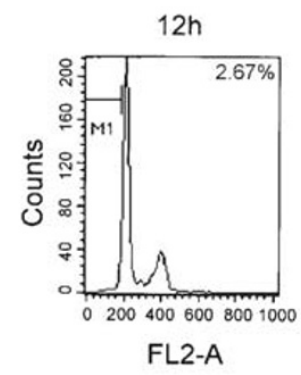

Fig 3. DNA fragmentation analysis for determination of apoptosis by FACS. (A) HeLa cells were infected with CVB3 and DNA content in the cells was determined at $0,1,6,12,18,24,30,36,42 \mathrm{~h}$ postinfection. Distinct subdiploid peak can be seen by $24 \mathrm{~h}$ postinfection. As time went by, the proportion of apoptotic cells continuously increased. (B) $20 \mu$ $M$ caspase-3 inhibitor DEVD-fmk was incubated with HeLa cells for 2 prior to CVB3 infection. Then DNA content was determined at $24,30,36,42 \mathrm{~h}$ postinfection. The results showed that regardless of the caspase inhibitor used, there was no significant alteration in apoptosis. 


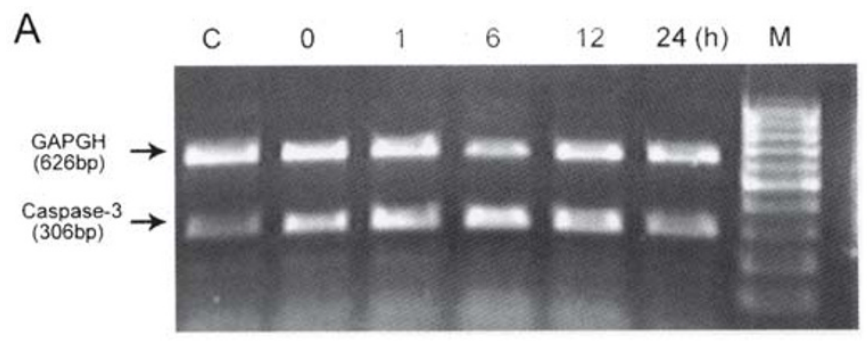

Caspase-3 activity in CVB3-infected HeLa cells

Caspase-3 activity increased at early stage of postinfection, and then returned to basal levels at longer periods of infection. In cells pre-incubated with DEVD-fmk, the cleavage of the substrate DEVD-pNA was partially prevented (Fig 6).
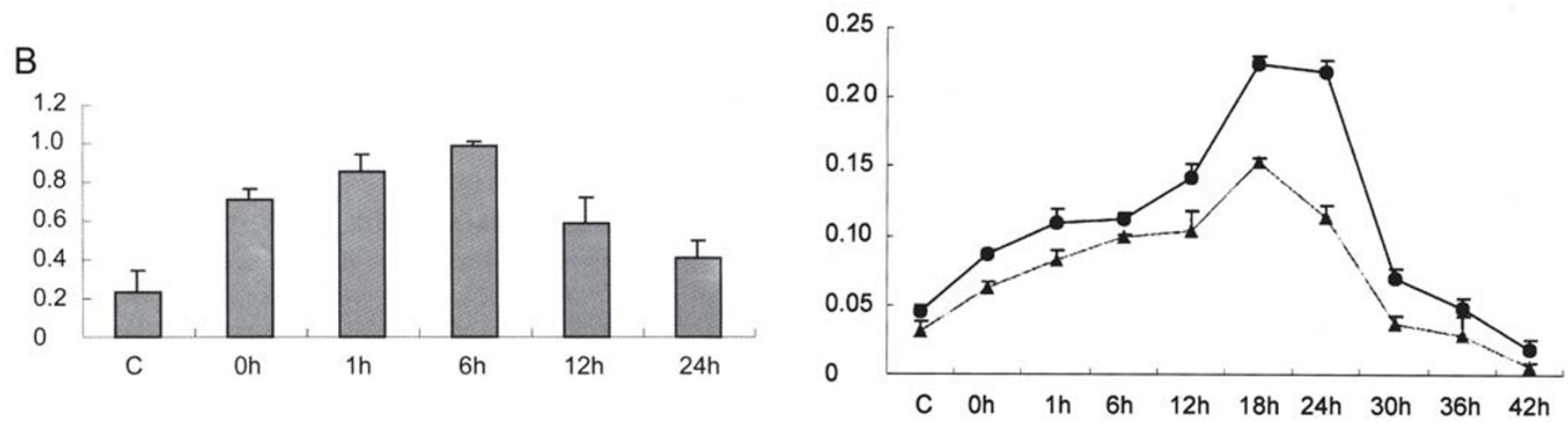

Fig 4. Measuring of caspase-3 mRNA synthesis by RT-PCR. Between 0 and $6 \mathrm{~h}$ postinfection, caspase- 3 mRNA synthesis increased rapidly, reaching a peak value, and then gradually fell to approach the level before the infection. (A) mRNA expression of caspase-3 gene detected by RT-PCR. GAPDH was as the loading control. (B) Ratio of quantity of caspase-3 mRNA to that of GAPDH mRNA at different time.

Fig 6. Caspase-3 activity in HeLa cells infected by CVB3. Cells were collected and processed as hereinbefore, pre-incubated or not pre-incubated with DEVD-fmk before the infection of CVB3. Samples were read at $405 \mathrm{~nm}$ in a microplate reader, and the higher OD value at $405 \mathrm{~nm}$ represents the higher enzyme activity of Caspase-3.

\section{Caspase-3 expression in CVB3-infected HeLa cells}

Between 0 and $6 \mathrm{~h}$ postinfection, caspase- 3 mRNA synthesis detected by RT-PCR increased rapidly, reaching a peak value, and then gradually fell approaching the level before the infection (Fig 4). The PCR product of 306bp was verified to be the same as caspase-3 cDNA by direct sequencing (data not shown). Western-blot analysis showed that within $42 \mathrm{~h}$ postinfection, the $32 \mathrm{kD}$ precursor protein of caspase-3 gradually increased its expression, so did its $20 \mathrm{kD}$ subunit (Fig 5).

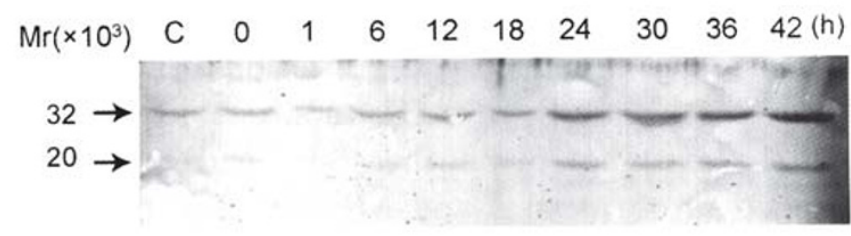

Fig 5. Western-blot analysis of the expression of caspase-3. Immunoblotting for the presence of caspase-3 showed that within $42 \mathrm{~h}$ postinfection, the $32 \mathrm{kD}$ precursor protein of caspase-3 gradually increased its expression, so did its $20 \mathrm{kD}$ subunit.

\section{DISCUSSION}

Apoptosis is a genetically controlled programmed event in response to a variety of physiological and non-physiological stimuli, inclusive of virus infection [20]. In the case of virus-infected cells, the early programmed cell death, comprising the induction of cellular endonucleases, could target replicating viral DNA and prevent virus production at a very early stage, thus limiting virus production and reducing spread of progeny virus. Many viruses have evolved genes encoding proteins that effectively suppress or delay apoptosis for the production of progeny, in addition to inducing apoptosis actively at late stages of infection. This process may be propitious to the spread of progeny to neighboring cells and protecting progeny virus from host immune responses[21]. In our research, we detected HeLa cell death after infecting the cells with CVB3 and found that although the cells showed visible morphological alteration signifying necrosis in the early stage of postinfection, evident apoptosis occurred only $24 \mathrm{~h}$ after the cocultivation. This result suggests that besides producing many proteins to induce apoptosis, CVB3 may 
also evolve the strategy of delaying apoptosis, thus facilitating its own replication. As for the early stage of morphological alterations consistent with CPE, Carthy et al proposed that they might result from the cleavage of specific structural proteins by viral proteases $2 \mathrm{~A}, 3 \mathrm{C}$, and $3 \mathrm{CD}[19]$.

Having established that CVB3 induces apoptosis in HeLa cells, we attempted to determine whether this effect was caspase mediated. Caspase-3 exists in cytoplasm in the form of zymogen with an $\mathrm{Mr}$ of $32 \mathrm{kD}$. Once activated, it is proteolytically cleaved into two polypeptides with $\mathrm{Mr}$ of 20 and $11 \mathrm{kD}$. Two p20/p11 heterodimers associate with each other to form the active caspase-3 tetrameric complex[22]. In this study, the expression of caspase-3 gene in CVB3-infected HeLa cells was detected at the transcription and translation levels respectively. Within $42 \mathrm{~h}$ after the infection, the protein expression of pro-caspase 3 gradually increased, so did its p20 subunit (Fig 5). The protein expression of caspase-3 gene is high enough to redeem the loss of precaspase-3 resulting from proteolytic cleavage. Thereby we could see from the result that the protein expression of precaspase- 3 was continually increasing along with that of its cleavage product. This result is different from that of Carthy et al, who demonstrated that the level of the $32 \mathrm{kD}$ precursor protein began to diminish between 7 and $8 \mathrm{~h}$ postinfection and was almost completely undetectable by $12 \mathrm{~h}[19]$. Our result of Western blot was consistent with the case of caspase-3 mRNA expression (Fig 4), which rapidly increased, reaching a peak value 0 to $6 \mathrm{~h}$ postinfection, and then dropped off approaching the level before the infection, indicating that rapid mRNA expression of caspase-3 occurs at early phase of postinfection of CVB3. It needs several hours for gene expression to start from transcription and translation up to playing the role of cleaving substrates, thus explaining our observation that the maximum caspase-3 activity and obvious apoptosis appeared by $24 \mathrm{~h}$ postinfection, while caspase-3 mRNA reached the peak value early between 0 and $6 \mathrm{~h}$. These results seem to suggest the involvement of casapse-3 in apoptosis induced by CVB3. During the late phase of postinfection, the protein level continuously increases (Fig 5), while the activity of Caspase3 tend to play down (Fig 6), probably due to the loss of enzyme activity. However, the decreasing activity of Caspase-3 can not explain the continually increasing DNA fragmentation detected by FACS (Fig 3), suggesting complexities in the process.

In order to clarify whether Caspase-3 activity directly results in the apoptosis in HeLa cells, or the activation of caspase-3 is a concomitant of apoptosis, we detected apoptosis by FACS in cells pre-incubated with Caspase-3 inhibitor. Beyond our expectation, although DEVD-fmk did partially inhibit Caspase-3 activity, the results of apoptosis detected by FACS had no distinct difference with those under the condition that Caspase-3 activity was not inhibited. Such outcome, with in-depth evidence of DNA fragmentation compared with morphological changes observed by Carthy et al, suggests that not only CPE, but apoptosis induced by CVB3 is not a direct consequence of the activation of caspase-3, or caspase-3 is not the only effector molecule in apoptotic cell death. This result is different from many previous observations which determined that DNA fragmentation during apoptosis is dependent on caspase activation[6, 18, 23, 24], but agrees with Izban et al, who found the caspase-independent apoptosis in Hodgkin and Reed-Sternberg cells, also utilizing DNA fragmentation as the criterion for the determination of apoptosis[25]. Some other biochemical mechanisms may participate in the process, whose role weakens the effect of inhibiting caspase-3 activity. Petit et al found the crucial role for mitochondria in the regulation of cell death. The loss of mitochondrial membrane potential is associated with the release of cytochrome $c$ and AIF, a flavoprotein, reported to directly cause chromatin condensation in isolated nuclei and participate in caspase-independent programmed cell death[18]. An AIF homologous protein AMID was also determined to induce a caspase-independent apoptotic pathway[26] Moreover, the study of AIF knockout mice suggests the existence of another cell death pathway independent of caspases and AIF[27]. Additionally, granzyme B is reported to mimic the cleavage specificity of the caspase family of pro-apoptotic cysteine proteases, thus permitting it to activate the generic cell suicide pathway present in virtually all cells $[28$, 29]. Further investigation should be made to find out which pathway CVB3-induced apoptosis adopts.

In conclusion, the present study demonstrates the characteristic changes of necrosis and the poste- 
rior apoptosis existing in HeLa cells infected with CVB3. The apoptosis touches upon the expression of caspase-3 and the activation of precaspase-3, but may be not the direct result of them, or may be the result of numerous elements inclusive of them. Further experiments should be done to explore other factors participate in the signaling transduction pathway of apoptosis.

\section{REFERENCES}

1. Muckelbauer J, Kremer M, Minor I, et al. The structure of Coxsackievirus B3 at 3.5 A resolution. Structure 1995; 3: 653-67.

2. Cheung $P$, Zhang $M$, Yuan J, et al. Specific interactions of HeLa cell proteins with Coxsackievirus B3 RNA: La autoantigen binds differentially to multiple sites within the 5' untranslated region. Virus Res 2002; 90:23-6.

3. Kerr JFR, Wyllie AH, Currie AR. Apoptosis: a basic biological phenomenon with wide-ranging implications in tissue kinetics. Br J Cancer 1972; 26:239-57.

4. Wyllie AH, Kerr JFR, Currie AR. Cell death: the significance of apoptosis. Int Rev Cytol 1981; 68:251-306.

5. Tsunoda L, Kurtz CL, Fujinami RS. Apoptosis in acute and chronic central nervous system disease induced by Theiler抯 murine encephalomyelitis virus. Virology 1997; 228:388-93.

6. Agol VI, Belov GA, Bienz K, et al. Two types of death of Poliovirus-infected cells: Caspase involvement in the apoptosis but not cytopothic effect. Virology 1998; 252: 343-53.

7. Zhang M, Zhang HQ, Xue SB. Effect of Bcl-2 and caspase3 on calcium distribution in apoptosis of HL-60 cell. Cell Res 2000; 10:213-20.

8. Granville DJ, Carthy CM, Yang D, Hunt DWC, McManus BM. Interaction of viral proteins with host cell death machinery. Cell Death Differ 1998; 5:653-9.

9. Geng YJ. Molecular signal transduction in vascular cell apoptosis. Cell Res 2001; 11:253-64.

10. Takahashi-A. Caspase: executioner and undertaker of apoptosis. Int J Hematol 1999 ; 70:226-32.

11. Duncan R, Muller J, Lee N, Esmaili A, Nakhasi HL. Rubella virus-induced apoptosis varies among cell lines and is modulated by Bcl-XL and Caspase inhibitors. Virology 1999; 255:117-28.

12. Lopez-Guerrero JA, Alonso M, Martin-Belmonte F, Carrasco L. Poliovirus induces apoptosis in the human U937 promonocytic cell line. Virology 2000; 272:25056.

13. Barco A, Feduchi E, Carrasco L. Poliovirus protease 3Cpro kills cells by apoptosis. Virology 2000; 266:352-60.

14. Agol V, Belov GA, Bienz K, et al. Competing death programs in Poliovirus-infected cells: commitment switch in the middle of the infectious cycle. J Virol 2000; 74: $5534-41$.
15. Borner C, Monney L. Apoptosis without caspases: an inefficient molecular guillotine? Cell Death Differ 1999; 6: 497-507.

16. Kitanaka C, Kuchino Y. Caspase-independent programmed cell death with necrotic morphology. Cell Death Differ 1999; 6:508-15.

17. Galvan V, Brandimarti R, Roizman B. Herpes Simplex Virus 1 blocks caspase-3-independent and caspase-dependent pathways to cell death. J Virol 1999; 73:3219-26.

18. Petit F, Arnoult D, Lelievre JD, et al. Productive HIV-1 infection of primary $\mathrm{CD} 4^{+} \mathrm{T}$ cells induces mitochondrial membrane permeabilization leading to a caspase-independent cell death. J Biol Chem 2002; 277:1477-87.

19. Carthy CM, Granville DJ, Watson KA, et al. Caspase activation and specific cleavage of substrates after Coxsackievirus B3-induced cytopathic effect in HeLa cells. J Virol 1998; 72:7669-75.

20. O? Brien V. Viruses and apoptosis. J General Virol 1998; 79:1833-45.

21. Teodoro JG, Branton PE. Regulation of apoptosis by viral gene products. J Virol 1997; 71:1739-46.

22. Fernandes-Alnemri T, Litwack G, Alnemri ES. CPP32, a novel human apoptotic protein with homology to Caenorhabditis elegans cell death protein Ced-3 and mammalian interleukin-1b -converting enzyme. J Biol Chem 1994; 269:30761-4.

23. Trapani JA, Jans DA, Jans PJ, Smyth MJ, Browne KA, Sutton VR. Efficient nuclear targeting of granzyme B and the nuclear consequences of apoptosis induced by granzyme B and perforin are caspase-dependent, but cell death is caspase-independent. J Biol Chem 1998; 273 : 27934-8.

24. Heibein JA, Barry M, Motyka B, Bleackley RC. Granzyme B-induced loss of mitochondrial inner membrane potential (D Ym) and cytochrome c release are Caspase independent. J Immunol 1999; 163:4683-93.

25. Izban KF, Ergin M, Huang Q, et al. Characterization of NF-闎 expression in Hodgkin's disease: inhibition of constitutively expressed NF-êB results in spontaneous Caspase-independent apoptosis in Hodgkin and reedsternberg cells. Mod Pathol 2001; 14:297-310.

26. Wu M, Zhai ZH, Shu HB. AMID, an AIF homologous protein, induces caspases-independent apoptosis. Cell Res 2002; 12:295.

27. Joza N, Susin SA, Daugas E, et al. Essential role of the mitochondrial apoptosis-inducing factor in programmed cell death. Nature 2001; 410:549-54.

28. Fernandes-Alnemri T, Armstrong RC, Krebs J, et al. In vitro activation of CPP32 and Mch3 by Mch4, a novel human apoptotic cysteine protease containing two FADDlike domains. Proc Natl Acad Sci USA 1996; 93:7464-9.

29. Darmon AJ, Ley TJ, Nicholson DW, Bleackley RC. Cleavage of CPP32 by granzyme B represents a critical role for granzyme B in the induction of target cell DNA fragmentation. J Biol Chem 1996; 271:21709-12. 